\title{
A Comparative Study to See the Impact of Yoga on Educational Aspiration (EA) and Test Anxiety (TA) among College Going Girls
}

\author{
Patelia Shraddha ${ }^{1}$, Dr Rathi Nanda ${ }^{2}$
}

\section{ABSTRACT}

A little bit of anxiety is normal; in fact, just like salt in the food, it is needed so that we remain disciplined, focused and aspired. The problem starts when this anxiety becomes so persistent as to start interfering with our daily life, and this is where yoga can help. The major aim of this research study was to explore the effect of yoga on educational aspiration and test anxiety of girls at the junior college level. A sample of 60 college going girls (age 17-18 years) was selected purposely from Nagpur, India. Data were collected by using the Educational Aspiration Scale (EAS) by V. P. Sharma and Test Anxiety Scale (TAS) developed by Sarason and Sarason. Student's paired t-test was applied for data analysis. It was found that a significant difference exists between two groups. Results showed that practice of yoga in a day to day life contributes significant enhancement of educational aspiration and considerable reduction of test anxiety. Therefore, it was concluded that making yoga a part of one's routine would help students in dealing with test anxiety and improving their aspiration towards education.

Keywords: Educational aspiration, Test anxiety, Yoga.

India as a developing country wants to increase the production and consequently aspires for advancement in science. It is the young generation, which has to shoulder its responsibility and take the nation ahead in all fields. As Emir has quoted in his speech; "the time has come to turn a new leaf in the history of our nation, where a new generation steps forward to shoulder the responsibility with their dynamic potential and creative thoughts”.

In 1916, Stanley Hall, the father of adolescent research proclaimed adolescence as a period of "storm and stress". It is a time of considerable changes in physical stature, physiological and endocrine changes and also changes in patterns of thinking and moral standard. It is a time of acquiring new skills, attaining mastery over environment, learning to handle new responsibilities

\footnotetext{
${ }^{1}$ Research Scholar, UGC NET Home Science, B.Ed, M.Sc.H.Sc. M.A. (Eng. Lit.)

${ }^{2}$ Ph.D. Human Development, Department of Human Development, L.A.D. \& S.R.P. College for Women, NAGPUR *Responding Author (C) 2016 I S Patelia, R Nanda; licensee IJIP. This is an Open Access Research distributed under the terms of the Creative Commons Attribution License (http://creativecommons.org/licenses/by/2.0), which permits unrestricted use, distribution, and reproduction in any Medium, provided the original work is properly cited.
} 


\section{A Comparative Study to See the Impact of Yoga on Educational Aspiration (EA) and Test Anxiety (TA) Among College Going Girls}

and gaining control over emotions and thoughts. Pandit Nehru has clearly stated, "The leaders of India's tomorrow will come out of the students of today” Patil (2011).

This has increased the responsibility of parents and educational institutions to train the new generation to take on new responsibilities. A developing society needs to create individuals who are physically as well as mentally healthy to meet the standards of excellence.

In today's world, education is a necessity, and for that reason, it has assumed an increasingly important role in future plans, especially for young people. During the educational process people gain necessary skills and competencies to be able to function on different competitive markets. Education, if looked at beyond its conventional boundaries, forms the very essence of all our actions. Educational aspiration reflects educational goals an individual sets for himself/herself. It is important as it encourages and energizes the individual to achieve them.

Now days, college has become stressful. It has caused a hectic life of attending classes, making notes, doing homework, and taking those dreaded exams. A 2011 National survey shows that more than $62 \%$ of students who withdrew from college were suffering from anxiety disorders. Test anxiety is the uneasiness, apprehension, or nervousness felt by students who had fear of failing an exam. Sweating, dizziness, headaches, racing heartbeats, nausea, fidgeting, and drumming on a desk are all common.

"Stress" is an outcome of modern lifecycle. It is produced out of dissatisfaction, frustration, and dejection when there is negative interaction been the self projection and the adverse internal as well as external environmental conditions. The goal of human life is opening, blossoming and playing, i.e. to explore all the possibilities within us, which is possible through yoga and meditation.

Yogic practices can help one in this respect by establishing and maintaining physiological balance in the body. Proper lifestyle including moderate exercise, proper diet, enough sleep, relaxation and positive thinking will definitely maintain the homeostasis and thus physical and mental health. Yoga is a great gift that has its origin in Indian civilization. The word Yoga means yoke or union; it is the union or integration of physical, emotional, mental and spiritual life. Yoga is thus disciplined way of achieving union or alignment with a higher state of consciousness. Gore (2011) cites the aim of yoga as to unite the mind, the body and the spirit.

Yoga says that we need to transcend the part of the mind and the feelings that are dominated by external sensations and their resulting thoughts and memories, in order to reach the deeper level of intelligence and consciousness that are connected with the soul. In the words of Amy Reed, the health benefits of yoga are also great and varied. From relieving stress to strengthening and 
toning muscle, integrating yoga positions and exercises into a daily routine can be beneficial on many levels.

Yoga is a part of the Indian lifestyle. Real comfort lies in good health. Disease free condition and contentment at the level of mind are essential components of happiness.

\section{Aims and Objectives}

- To study the educational aspiration (EA) of college going girls.

- To analyze the test anxiety (TA) of college going girls.

- To evaluate the impact of Yoga on educational aspiration and test anxiety of college going girls.

\section{Hypothesis}

- There exists significant difference in educational aspiration and test anxiety between yogic group and non-yogic group of college going girls.

\section{METHODOLOGY}

\section{Sample}

- Class: College going

- Age group:17-18 years

- Gender: Female

- Demography: Urban

Sample size

- Total sample size: 60

- Group 1: 30

- Group 2: 30

Groups

i. Group 1: Yogic group

ii. Group 2: Non-Yogic group

Tools

For the present work the standardized tool used were:

- Educational Aspiration Scale by Dr. V. P. Sharma.

- Test Anxiety Scale by Sarason and Sarason

\section{Method and Procedure}

Thirty girls who practices yoga in their daily routine (Group 1: Yogic group) were contacted and the above psychological tests were conducted on them. Whereas remaining 30 girls who were not in practice of yoga in their routine (Group 2: Non-Yogic group) were randomly selected from one of the college of Nagpur. 
The data collected through the above scale was subjected to statistical analysis and initially mean and standard deviation were drawn out. Student's paired test was applied to find out the difference between two groups. The paired t- test is used to compare two population means where you have two samples in which observations in one sample can be paired with observations in other sample.

\section{Ethical Considerations}

Verbal consent for participating in the research was obtained. Participants were explained the purpose of conducting research and were informed about privacy and confidentiality of the data collection.

\section{STATISTICAL ANALYSIS}

Struwig and Stead (2007) explained that sometimes it is difficult to make sense of the raw data. In most cases the data is often large and it is difficult to make connection between pieces of information. In order to make sense of the raw data, it is first necessary to summarize it by coding it and analyzing it through a certain program which might be qualitative or quantitative analysis program.

The present study was intended to compare the effect of yoga on test anxiety and educational aspiration of college going girls. Yoga was treated as independent variable whereas test anxiety and educational aspiration were treated as dependent variables.

Initially the data was subjected to descriptive statistical techniques - mean and standard deviation for both the variables. The values are displayed in table no.1.

Table No.1: Mean and SD of the variables:

\begin{tabular}{|c|l|l|l|c|}
\hline \multicolumn{5}{|c|}{ Paired Samples Statistics } \\
\hline & & \multicolumn{1}{|c|}{ MEAN } & N & SD \\
\hline YOGIC Group & EA & 41.5 & 30 & 10.9 \\
\cline { 2 - 5 } & TA & 12.3 & 30 & 2.8 \\
\hline $\begin{array}{c}\text { Non-YOGIC } \\
\text { Group }\end{array}$ & EA & 35.03 & 30 & 10.5 \\
\cline { 2 - 5 } & TA & 24.5 & 30 & 3.3 \\
\hline
\end{tabular}

Examination of the above table no.1 reveals that the data is distributed normally. This could be verified from the SD's associated with the means.

The mean score for the measurement of educational aspiration of the college going girls performing yogic practices clearly signifies their stand on percentile $\mathrm{P}_{75}$ whereas those not practicing yoga stood on percentile $\mathrm{P}_{60}$. Further glance to the mean scores exhibited lower level of test anxiety in the college going girls practicing yoga in their daily routine. 
However, it is not possible to infer confidently only on the basis of descriptive statistics. Hence the data was subjected to paired ' $t$ ' test. The values are displayed in table no.2

Table No.2: Mean, SD and t-value of Educational Aspiration (EA) and Test Anxiety(TA) of the College going girls:

\begin{tabular}{|l|l|l|l|l|c|}
\hline \multirow{2}{*}{} & \multicolumn{2}{|c|}{ Paired Differences } & \multicolumn{1}{c|}{ df } & Sig. (2-tailed) \\
\cline { 2 - 7 } & \multicolumn{1}{|c|}{ SD } & \multicolumn{1}{c|}{ t } & \multicolumn{1}{c|}{ df } & $(\mathrm{p}<0.0001)$ \\
\hline EA Scores & 6.47 & 0.4 & 14.69 & 29 & $(\mathrm{p}<0.01)$ \\
\hline TA Scores & -12.2 & -1 & 2.33 & 29 & \\
\hline
\end{tabular}

Table no. 2 reveals that the computed t- value for both educational aspiration as well as test anxiety is considered to be extremely statistically significant.

\section{RESULTS AND DISCUSSION}

The present study was undertaken with a sensible thought that large population of adolescents have been gripped with mental health problems like stress, anxiety, and resulted into lowering of concentration level and academic performance. The students who are in their adolescent age undergo many physical and psychological changes and experience a lot of stress in their critical period of life.

Based on the findings of t-ratio, a significant positive effect of performing yoga on the level of educational aspiration as well as test anxiety was observed i.e. test anxiety was found to be lesser in college girls practicing yoga as compared to those who are not in practice of yoga in their daily routine. The results further revealed significant and encouraging impact of following yoga on the enhancement of educational aspiration.

\section{Implications:}

The present study develops interest among educationists, researchers and teachers to implement yogic practices at each level of education and scheduling of such training in the curriculum. It is also helpful for solving the psychological problems of adolescents and reducing the suicidal cases that are enhancing in the present scenario due to cut throat competitions, parental pressure, examination phobia, etc.

\section{Limitations of Study:}

1. The present study was conducted on female students only. Study can be undertaken on male students.

2. In the present study, subjects from colleges of urban area were selected. Study can be undertaken on colleges from sub-urban and rural area.

3. The present study was conducted on college going girls to compare the impact of yogic practices on educational aspiration and test anxiety. The study can be undertaken on other 


\section{A Comparative Study to See the Impact of Yoga on Educational Aspiration (EA) and Test Anxiety (TA) Among College Going Girls}

variables like overall mental health, physical health and others similar related psychological and physiological states.

4. The sample size was limited to 60 college going girls only. It can be increased for better results.

\section{Acknowledgments}

I express my sincere thanks and indebtedness towards my Guide for her scholarly guidance and inspiring suggestions in carrying out my research work. My heartfelt gratitude towards the participants for providing valuable cooperation and help in the course of data collection. Lastly, I gratefully acknowledge the support of my family.

\section{REFERENCES}

Anxiety. (2015,May 13).In Psychology Wiki. Retrieved from

http://psychology.wikia.com/wiki/Anxiety

Grasgreen A. (2012). Students Rate Mental Services. Retrieved from

https://www.insidehighered.com/news/2012/10/30/colleges-dont-always-help-mentalhealth-issues-student-survey-shows

Gore, M, (2010), “ANATOMY AND PHYSIOLOGY OF YOGIC PRACTICES”, New Age Books,New Delhi,ISBN:978-81-7822-305-6,Page:xv-Xvi

Gore C. (2011).”YOGA and HEALTH”, Sports Publication, New Delhi, ISBN:978-8178796086, Page: 43

Levesque, R. (2011). Educational Aspirations, Encyclopedia of Adolescence (Vol.1,p.807). Springer New York

Patil, P. (2011), "Universities should provide conducive environment for healthy growth of students”, University News, 49, 7, Pp. 24-25. Retrieved from http://shodhganga.inflibnet.ac.in/bitstream/10603/6684/6/06_chapter1.pdf.pdf

Paweł S. (2011). Educational Aspiration, Working Papers, 10(1).Retrieved from http://www.wne.uw.edu.pl/inf/wyd/WP/WNE_WP50.pdf

Reed A. (2016). Yoga Twist Sequence for Beginners. Retrieved from http://www.ehow.com/videos-on_7627_yoga-twist-sequence-beginners.html

Rohini M.(2012). Importance of education in society. Retrieved from mrseamusic.Blogspot .in/2012/02

Rosie S. (2004) Statistics , Mathematical Learning Support Center , Retrieved from : http://www.statstutor.ac.uk/resources/uploaded/paired-t-test.pdf

Sirshree, (2008), “COMPLETE MEDITATION”, WOW Publishing Pvt. Ltd. , Pune, ISBN: 978-81-906627-6-5,Page:116

Struwig, F.W., \& Stead, G.B. (2007). PLANNING, DESIGNING and REPORTING. Cape Town: Pearson, ISBN:1868910814 9781868910816, Page150

Upadhyaya, 2R and Sharma G,(2008), “LEARN MEDITATION”, Lotus Press, New Delhi , ISBN:81-8382- 037-9, Page: 124 